
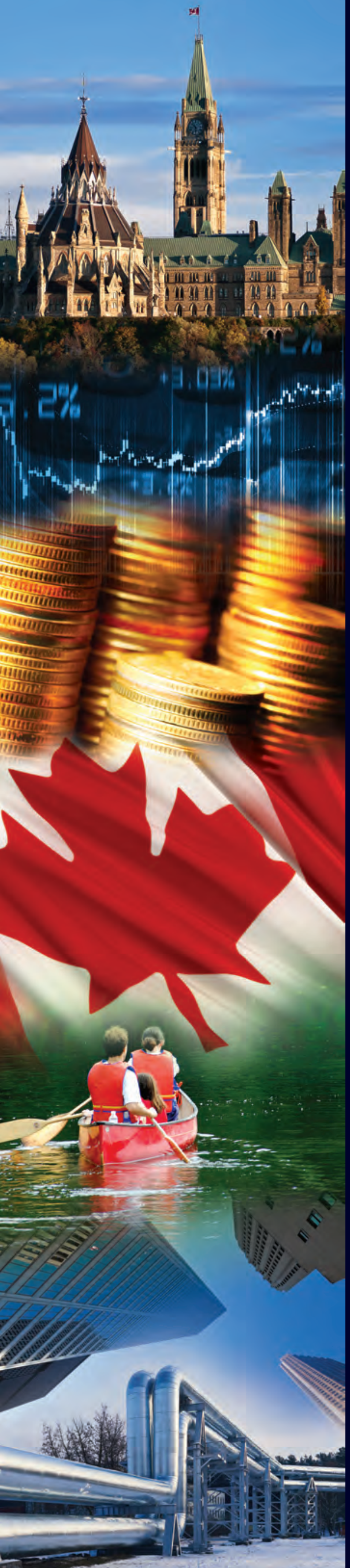

COMMENTARY

NO. 528

\title{
Dammed If You Do: How Sunk Costs Are Dragging Canadian Electricity Ratepayers Underwater
}

Canada has three mega-projects underway to generate hydroelectricity. But a comparison of their costs relative to the alternatives raises the question of whether it's time to pull the plug on them.

\section{A.J. Goulding} with research support from Jarome Leslie 


\section{THE C.D. HOWE INSTITUTE'S COMMITMENT TO QUALITY, INDEPENDENCE AND NONPARTISANSHIP}

\section{ABOUT THE AUTHORS}

\section{A.J. Goulding is President of London Economics International LLC ("LEI"). He has advised provincially owned hydro companies, IPP associations, and consumer groups on Canadian and international electricity market related issues.}

Jarome Leslie is a Senior Consultant with LEI.

Commentary No. 528 January 2019 Energy and Natural RESOURCES
The C.D. Howe Institute's reputation for quality, integrity and nonpartisanship is its chief asset.

Its books, Commentaries and E-Briefs undergo a rigorous two-stage review by internal staff, and by outside academics and independent experts. The Institute publishes only studies that meet its standards for analytical soundness, factual accuracy and policy relevance. It subjects its review and publication process to an annual audit by external experts.

As a registered Canadian charity, the C.D. Howe Institute accepts donations to further its mission from individuals, private and public organizations, and charitable foundations. It accepts no donation that stipulates a predetermined result or otherwise inhibits the independence of its staff and authors. The Institute requires that its authors disclose any actual or potential conflicts of interest of which they are aware. Institute staff members are subject to a strict conflict of interest policy.

C.D. Howe Institute staff and authors provide policy research and commentary on a non-exclusive basis. No Institute publication or statement will endorse any political party, elected official or candidate for elected office. The views expressed are those of the author(s). The Institute does not take corporate positions on policy matters.
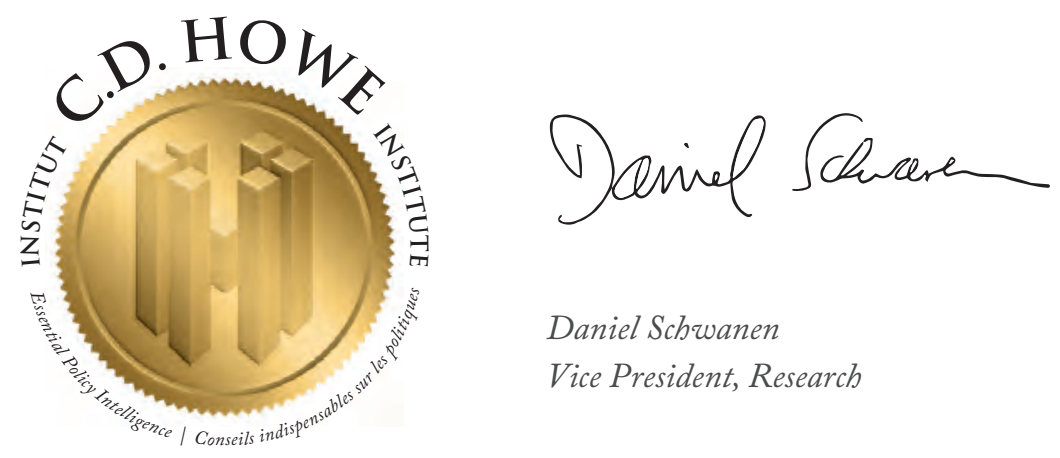

Daniel Schwanen

Vice President, Research 


\section{THE STUDY IN BRIEF}

The push towards renewable energy sources has prompted major investments in mega-projects to generate hydroelectricity. However, government decisions to make such large investments in generating capacity must be scrutinized for economic soundness - particularly relative to the costs of alternatives for producing this power.

Canada has several large hydroelectricity projects presently under construction including three that are the subject of this paper: Site $\mathrm{C}$ on the Peace River in northern British Columbia, Keeyask on the Nelson River in Manitoba, and Muskrat Falls on the Churchill River in Labrador. Each of these projects represents a multi-billion dollar upfront investment by public entities in long-lived generation capacity.

This study examines the cost-effectiveness of these hydro projects by comparing the costs of equivalent generation from carbon cost adjusted combined cycle natural gas turbines (CCGT). The analysis demonstrates that the levelized costs from the Site $\mathrm{C}$ and Keeyask projects may exceed the costs of alternative CCGT generation. The study notes that risks of building large generation capacity in anticipation of uncertain future demand for electricity and contends that, relative to large hydro projects, the roll-out of CCGT generation can be more flexibly timed (and paired with environmental initiatives) to meet demand as it materializes.

Even building-in the likely costs of cancellation, the author concludes that present economics would favour cancelling Site $\mathrm{C}$ and Keeyask and replacing the respective capacity with equivalent dispatchable CCGT generation capacity. The study shows that replacing Site $\mathrm{C}$ or Keeyask with equivalent CCGT capacity is cost effective even when applying a lower discount rate.

While an emphasis on renewables generation has motivated these major hydroelectric projects, the analysis shows that Site $\mathrm{C}$ exceeds the levelized cost of a CCGT alternative that faces a $\$ 50 /$ tonne carbon price. Moreover, drawing from results in recent renewable energy procurement, the study observes that wind generation can provide a much lower levelized cost of zero-emission electricity than such large-scale hydro projects.

This study concludes by recommending that provinces re-examine the economics of these projects and consider cancelling projects which have more cost effective alternatives. To avoid uneconomic projects in the future, the report also recommends strengthening institutional independence - in particular, by ensuring independent regulatory review for mega-projects and leveraging greater private-sector discipline for the design and delivery of major electricity projects.

C.D. Howe Institute Commentary $(\mathrm{C}$ is a periodic analysis of, and commentary on, current public policy issues. Michael Benedict and James Fleming edited the manuscript; Yang Zhao prepared it for publication. As with all Institute publications, the views expressed here are those of the authors and do not necessarily reflect the opinions of the Institute's members or Board of Directors. Quotation with appropriate credit is permissible.

To order this publication please contact: the C.D. Howe Institute, 67 Yonge St., Suite 300, Toronto, Ontario M5E 1J8. The full text of this publication is also available on the Institute's website at www.cdhowe.org. 


\section{Several large-scale Canadian hydro projects now under construction face significant cost overruns and will potentially be uneconomic for decades if completed.}

While cancellation of one or more of these projects may be the best choice economically, political calculations make termination difficult. To prevent such mistakes in the future, provinces need to strengthen independent, apolitical regulatory and market institutions, adopt a more rigorous analytical process in evaluating such large-scale projects and expand the role of the private sector in risk-sharing, project ownership and delivery. This Commentary demonstrates that a combination of dispatchable (on demand) and non-dispatchable energy sources procured in smaller sizes closer to the period of demonstrated need, would be more cost-effective.

We begin with an overview of the current status of three large hydro projects, then describe how sunk costs need to be a major factor in decisionmaking. This discussion is followed by an examination of the project-completion levelized cost of energy $(\mathrm{LCOE})^{1}$ vis-à-vis replacement with natural-gas fired resources. It also examines the case for project deferral due to delays in actual power needs. Finally, we address the common arguments of project proponents and make policy recommendations to prevent these costly mistakes.

\author{
SEVERAL POTENTIALLY \\ UNECONOMIC PROJECTS ARE \\ CURRENTLY UNDER CONSTRUCTION
}

Three large-scale Canadian power-sector projects currently under construction stand out for their potentially poor economic prospects. These include the Site $\mathrm{C}$ project in British Columbia, the Keeyask project in Manitoba, and Muskrat Falls in Newfoundland and Labrador. Others under construction or proposed projects may face financial challenges as well.

Site C: The Site C Clean Energy Project, owned and operated by BC Hydro, will include a dam and a 1,132 megawatt (MW) hydroelectric generating station on the Peace River in the northeast of the province. ${ }^{2}$ The project will join an existing river system consisting of the W.A.C. Bennett Dam and Peace Canyon Dam. Construction on Site C commenced in July 2015, with total expenditures amounting to $\$ 2.1$ billion, approximately 25 percent of the original budget as of December 2017. ${ }^{3}$ However, latest estimates place projected total costs at $\$ 10.7$ billion with an expected completion date of

The authors would like to thank Grant Bishop, Marcel Boyer, Rick Jennings, Pierre-Olivier Pineau, Grant Sprague and anonymous reviewers for helpful comments on an earlier draft. The authors retain responsibility for any errors and the views expressed. Due to the time required for the C.D. Howe Institute's rigorous peer review process, data in the paper are as of May 2018. For an updated version of the analysis using data as of October 2018, please see the accompanying addendum. The author regularly provides expert testimony in regulatory proceedings for electricity rates and policy advice on electricity market design in Canadian provinces, including having worked on behalf of Clean Energy BC and testified on behalf of small industrial electricity consumers in Manitoba. The author has not acted in any regulatory proceedings concerning approvals for the projects discussed in this paper.

1 The LCOE is an industry-accepted measure for detailed analysis and decisionmaking that represents price for plant output that, over the plant's life, will be sufficient to provide owners with a return on their capital while covering all operating costs.

2 BC Hydro. Reply Submission 2017. Table B-3-2“Project Overview." Site C. https://www.sitecproject.com/about-site-c/ project-overview.

3 BC Hydro. Site C Clean Energy Project - Annual Progress Report No. 2. March 2018. 


\section{Table 1: List of Acronyms}

\begin{tabular}{ll}
\hline Acronym & Definition \\
\hline AEO & Annual Energy Outlook \\
\hline AESO & Alberta Electric System Operator \\
\hline BC & British Columbia \\
\hline BC Hydro & British Columbia Hydro and Power Authority \\
\hline BCUC & British Columbia Utilities Commission \\
\hline CAD & Canadian Dollar \\
\hline Cal-ISO & California Independent System Operator \\
\hline CCGT & Combined cycle gas turbine \\
\hline CEC & California Energy Commission \\
\hline CONE & Cost of New Entry \\
\hline CPCN & Certificate of Public Convenience and Necessity \\
\hline CPUC & California Public Utilities Commission \\
\hline EIA & Energy Information Administration \\
\hline EIM & Energy Imbalance Market \\
\hline EV & Electric vehicle \\
\hline GWh & Gigawatt hour \\
\hline HVDC & High Voltage Direct Current \\
\hline ICAP & Installed capacity \\
\hline IESO & Independent Electricity System Operator \\
\hline IRENA & International Renewable Energy Agency \\
\hline
\end{tabular}

\begin{tabular}{ll} 
Acronym & Definition \\
\hline IPP & Independent power producer \\
\hline ISO & Independent System Operator \\
\hline ISO-NE & ISO New England \\
\hline ITMO & Internationally transferred mitigation outcome \\
\hline kW & Kilowatts \\
\hline LCOE & Levelized cost of energy \\
\hline LEI & London Economics International \\
\hline MB & Manitoba \\
\hline MH & Manitoba Hydro \\
\hline MPUB & Manitoba Public Utilities Board \\
\hline MISO & Minnesota Independent System Operator \\
\hline MW & Megawatt \\
\hline MWh & Megawatt hour \\
\hline NL & Newfoundland and Labrador \\
\hline NL Hydro & Newfoundland and Labrador Hydro \\
\hline O\&M & Operations \& maintenance \\
\hline OIC & Order-in-Council \\
\hline PPA & Power Purchase Agreement \\
\hline USD & US Dollar \\
\hline WACC & Weighted average cost of capital \\
\hline
\end{tabular}

2024 - up from $\$ 7.9$ billion and 2020, respectively, as initially forecasted in 2010., ${ }^{4,6}$

Meanwhile, BC Hydro forecasts a need for new capacity by 2023 in tandem with a need for new energy by $2028 .{ }^{7}$ Should the project be axed, the termination and site remediation costs are estimated to be $\$ 1.8$ billion. $^{8}$

Keeyask: The Keeyask Project, a 695-MW hydroelectric generating station, will be located on the Nelson River, 725 kilometres north of Winnipeg. The project is being developed by the Keeyask Hydropower Limited Partnership, led by Manitoba Hydro and four Manitoba First Nations. ${ }^{9}$ Since construction commenced in July 2014, expenditures have totaled $\$ 4.2$ billion, nearly

4 Ibid.

5 BC Hydro. Site C Capital Cost Estimate. 2014.

6 "Province announces Site C Clean Energy Project." Site $C$.

7 BC Hydro. BC Hydro Reply Submission. 2017. (p. 15)

8 British Columbia Utilities Commission. British Columbia Utilities Commission Inquiry Respecting Site C: Executive Summary of the Final Report to the Government of British Columbia. November 2017. (p. 3)

9 “Keeyask Generating Station." Manitoba Hydro. 


\section{Figure 1: Selected Large Hydro Projects}
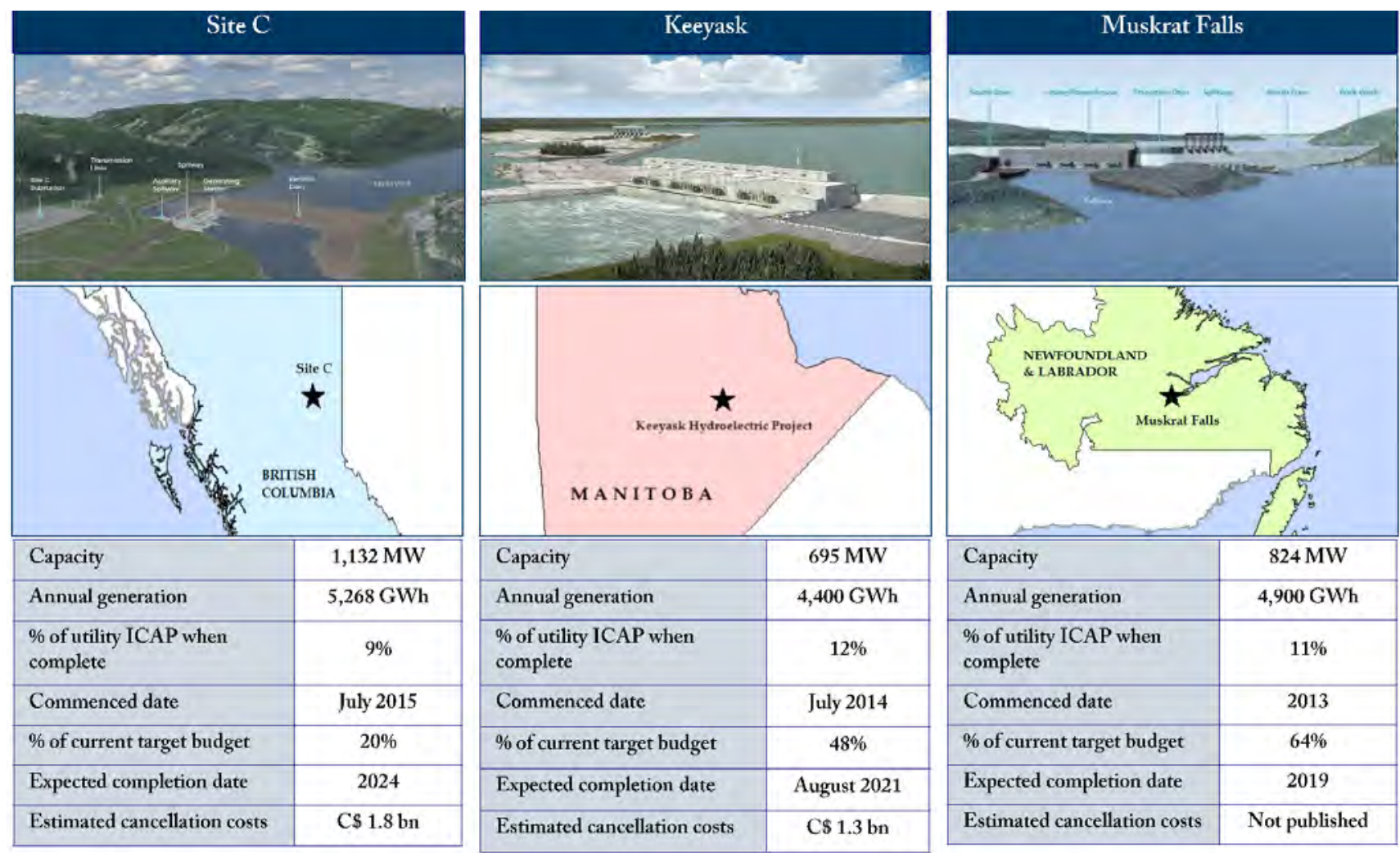

Sources: BC Hydro, Nalcor Energy and Manitoba Hydro.

half of the target budget as of December 2017. ${ }^{10,11}$ However, the latest projected total costs are some $\$ 8.7$ billion, with a completion date of August 2021, compared to $\$ 5.6$ billion and 2019 , respectively, as forecasted in 2011). ${ }^{12,13}$

Recent load forecasts indicate no need for new generation for domestic load before approximately 2033. ${ }^{14}$ Based on a 2017 Manitoba Hydro analysis, estimated cancellation costs of Keeyask were approximately $\$ 1.35$ billion. ${ }^{15}$

Muskrat Falls: Nalcor Energy's Muskrat Falls

10 Keeyask Hydropower Limited Partnership. Construction Begins on Keeyask Generating Station. July 2014.

11 Manitoba Hydro. Manitoba Hydro 2017/18 E 2018/19 General Rate Application: GSS-GSM/MH I-3a-c. September 2017. (p. 5)

12 Keeyask Hydropower Limited Partnership. Control Budget for Keeyask Generating Station Revised 2017. March 2017.

13 Keeyask Hydropower Limited Partnership. \$5.6 Billion Keeyask Generating Station Announced. June 2011.

14 Keeyask Hydropower Limited Partnership. Control Budget for Keeyask Generating Station Revised 2017.

15 Cancellation costs include Manitoba Hydro costs associated with managing the ramifications resulting from cancelling the project such as demobilization and salvage, short-term employee contract buyouts, breakage fees from various contracts, site and environmental remediation, long term environmental monitoring, interest and escalation. See Manitoba Hydro. Manitoba Hydro 2017/18 Eं 2018/19 General Rate Application: GSS/GSM/MH I-4. September 2017(p. 6). 
Project, located in Labrador's interior, will include an 824-MW hydroelectric generating facility, approximately 1,600 kilometres of transmission lines across the province and an additional transmission line connecting Newfoundland and Labrador. ${ }^{16}$ While construction on the project began in 2013, it was 88 percent complete as of November 2017, at which point total expenditures amounted to $\$ 8.1$ billion or approximately 64 percent of the target budget. ${ }^{17}$ Following numerous budget revisions, the latest projected total cost is $\$ 12.7$ billion, with the project expected to generate first power by 2019 , compared to $\$ 6.2$ billion and 2017 , respectively, as predicted in 2012. ${ }^{18,19,20}$

Newfoundland and Labrador Hydro load projections have deteriorated substantially since the project was approved in 2012. In that year, load expectations in 2020 were in excess of seven terawatt hours (TWh) but, as of May 2016, that level is not expected until $2036 .^{21}$

To date, termination costs have not been quantified. According to Nalcor CEO Stan Marshall, "the costs were so high, and the consequences so painful, that such an undertaking wasn't even worth" his time. ${ }^{22}$ Concerned about the monumental cost overruns, the Newfoundland and Labrador government commissioned an inquiry in November 2017 but did not explicitly state cancellation costs as an item to be considered in their Terms of Reference. At time of writing this Commentary, the inquiry was set to be completed on or before December 31, 2019. ${ }^{23}$ For our part, we have calculated cancellation costs for Muskrat at $\$ 1.47$ billion, based on the estimated average cancellation cost per $\mathrm{kW}$ of Site $\mathrm{C}$ and Keeyask. (Details of these calculations are provided in online Appendix 3.)

\section{SOUND DECISIONMAKING DEPENDS ON A PROPER UNDERSTANDING OF SUNK COSTS.}

To determine whether to proceed with each of the aforementioned projects, the going-forward costs need to be compared on a levelized basis against alternatives. ${ }^{24}$ Such an analysis, properly performed, requires ignoring expenditures to date, or sunk costs, that are irreversible. Policymakers often justify proceeding with uneconomic projects due to the significant amount of money that has already been spent. However, the decision whether to proceed

16 “Project Overview." Nalcor Energy.

17 Nalcor Energy. Muskrat Falls Project Update. November 2017. January 16, 2018. (p. 4, 11)

18 For fuller discussion, see Nalcor Energy. Muskrat Falls Project Update. June 2017. (p. 11); "Muskrat Falls Generating Project," Nalcor Energy. https://muskratfalls.nalcorenergy.com/project-overview/muskrat-falls-hydroelectric-generationfacility/; and "Lower Churchill Project to Become a Reality" Government of Newfoundland and Labrador. http://www. releases.gov.nl.ca/releases/2010/exec/1118n06.htm.

19 “Muskrat Falls Generating Project.” Nalcor Energy. <https://muskratfalls.nalcorenergy.com/project-overview/muskrat-fallshydroelectric-generation-facility/>.

20 "Lower Churchill Project to Become a Reality." Government of Newfoundland and Labrador.

21 Nalcor Energy. Muskrat Falls Project Update. July 24, 2016.

22 "NDP calls for study into cost of halting work on Muskrat Falls powerhouse.” Nalcor Energy. 2016. http://www.cbc.ca/ news/canada/newfoundland-labrador/muskrat-falls-ndp-1.3659518.

23 Newfoundland and Labrador Regulation 101/17. Commission of Inquiry Respecting the Muskrat Falls Project Order. November 20, 2017.

24 While this Commentary focuses on comparing completion costs with the costs of gas turbines, imports and renewables with storage, the analysis should also take a broad view of variables, including demand response, energy efficiency and distributed energy resources, using an integrated resource-planning process. In the case of BC imports, while these may violate the "self-sufficiency" requirement of the province's Clean Energy Act, this self-imposed restriction could be amended. 


\section{Box 1: Exploring the Concept of Sunk Costs}

A simple example, Investment A, may be helpful. Suppose someone has invested $\$ 100$ and their cost of funds is 5 percent. Now, assume that they have been told that they can either abandon the investment and receive nothing, or they can invest an additional $\$ 100$ and receive $\$ 2$ per year in income in perpetuity. Clearly, to recover at least the cost of the incremental funds, the follow-on investment would need to yield $\$ 5$ per year; the investor should decline to make any further investments in the venture and take the loss.

\begin{tabular}{lcc} 
& $\begin{array}{c}\text { Investment } \\
\text { A }\end{array}$ & $\begin{array}{c}\text { Investment } \\
\text { B }\end{array}$ \\
\hline Initial investment & $\$ 100$ & $\$ 100$ \\
\hline New investment & $\$ 100$ & $\$ 100$ \\
\hline Return & $\$ 2$ & $\$ 8$ \\
\hline Write down & $\$ 0$ & $\$ 100$ \\
\hline New investment return & $2 \%$ & $8 \%$ \\
\hline Initial investment return & $0 \%$ & $0 \%$
\end{tabular}

Let us extend the example further with Investment B. Suppose simultaneously the investor was offered a different opportunity - to invest $\$ 100$ in a new venture that would yield $\$ 8$ per year in perpetuity. While this second investment is evidently higher yielding than continuing in the first, and should be the obvious choice, many investors might wrongly choose Investment A and shun Investment B to avoid admitting the loss. Yet by choosing Investment B, they would have an extra $\$ 6$ in perpetuity to spend.

with a project should be determined by the yetto-be-spent costs, instead of costs already spent. ${ }^{25}$ Factoring sunk costs into decisionmaking results in a phenomenon known as the "sunk-cost fallacy."

Politics make the decision to cancel (or defer) a project even more difficult as some politicians perceive project terminations as an admission of failure. Alongside the funds spent, politicians invest their reputation and electability. BC Premier John Horgan has justified completing Site $\mathrm{C}$ by saying, "We will not ask British Columbians to take on $\$ 4$ billion in debt with nothing in return for the people

25 Regulators in similar circumstances have allowed amortization of cancellation costs to avoid rate shock, and regulators who do not currently allow such practices should adjust them accordingly. The benefits of the cancellation accrue to future ratepayers in the same way that the costs would have, had it been built. Immediate expensing of cancellation costs leads to intergenerational equity issues. For example, the Public Utilities Board of Manitoba approved the recovery of $\$ 380$ million of sunk costs related to the cancelled Conawapa Generating Station in a regulatory deferral account with amortization of the costs on a straight-line basis over a 30-year-period beginning on April 1, 2018. See Public Utilities Board of Manitoba. Order No. 59-18. May 1, 2018. p.22. 
of this province. ${ }^{26}$ However, careful economic analysis suggests that $\mathrm{BC}$ ratepayers may, in fact, end up paying more by the project continuing than they would if they simply paid off the debt already incurred and pursued an alternative path. As we will see, continuing with construction on some of Canada's large-scale hydro projects may result in a similar loss of welfare for the ratepayers who will ultimately pay the bill.

\section{LEVELIZED COSTS FOR THE SUBJECT PROJECTS ARE DRIVEN BY SUBSTANTIAL CAPITAL COSTS}

To determine whether the decision to continue construction is rational, we first calculated the LCOE for each of the three plants examined here based solely on so-called "go-forward" costs. We then compared these go-forward LCOEs to alternative approaches to meeting current needs, factoring in the cost of negative externalities. In addition to the go-forward costs, key assumptions for calculating the LCOE include the amortization period, the cost of capital, fixed and variable operating and maintenance costs, and expected annual production. While point estimates are provided below, they are tested against a range of possible outcomes in a subsequent section.

Go-forward capital costs: These costs (Figure 1) are based on recent announcements regarding amounts remaining to be spent on each of the projects, although it is likely that pressure for ongoing expenditure to create "facts on the ground"

\begin{tabular}{|c|c|c|c|}
\hline Values in $\mathrm{C} \$$ billion & Site C & Keeyask & $\begin{array}{c}\text { Muskrat } \\
\text { Falls }\end{array}$ \\
\hline Current budget & 10.7 & 8.7 & 12.7 \\
\hline Current expenditures & 2.1 & 4.2 & 8.2 \\
\hline Go forward costs & 8.6 & 4.5 & 4.5 \\
\hline Date of assessment & 31-Dec-17 & 31-Dec-17 & $28-\mathrm{Feb}-18$ \\
\hline \multicolumn{4}{|c|}{$\begin{array}{l}\text { Sources: BC Hydro. Site C Clean Energy Project - Annual } \\
\text { Progress Report No. 2. March 2018; Manitoba Hydro. } \\
\text { Undertaking \#57. February 2018; Nalcor Energy. Muskrat Falls } \\
\text { Project, Monthly Report - February 2018. April 20,2018.p. 8. }\end{array}$} \\
\hline
\end{tabular}

will make it more difficult to cancel the projects, the costs remaining are based on the most recent data available. ${ }^{27}$ Assumed go-forward costs appear in Table 2. We include the costs of transmission because of the location-constrained nature of these specific hydroelectric resources.

Amortization: A key component of the LCOE is the length of the period over which capital costs are recovered. We have used a 60 -year amortization period, which is consistent with the longest power purchase agreement (PPA) offered to hydroelectric independent power producers (IPP) in Canada. ${ }^{28}$ While hydro assets are long lived, components require periodic maintenance and replacement, and experience suggests that parts of civil works may need to be replaced as well after several decades of use.

26 "Government will complete Site C construction, will not burden taxpayers or BC Hydro customers with previous government's debt”. BC Gov News. December 11, 2017.

27 This Commentary is based on the most recent data available at the time of drafting (May 2018). Due to the nature of this analysis, the economics of these projects improves as more capital is sunk. However, if we assume significant additional expenditure at Site $\mathrm{C}$, our calculations suggest it would still be unfavourable. As noted previously, analysis using more recent data appears in the addendum.

28 BC Hydro issued a 61-year PPA to Capstone Infrastructure Corporation for its 16-MW Sechelt hydro project. See BC Hydro. Independent Power Producers (IPPs) currently supplying power to BC Hydro. November 2012. In Ontario, PPAs for hydroelectric power were signed for up to 50 years under its Hydroelectric Energy Supply Agreement procurement program. See IESO. Progress report on contracted supply. June 2015. 
Cost of capital: A fundamental principle of corporate finance is that the cost of capital should reflect the risks of the project itself, rather than the generalized cost of funds available to the investor. Given that a substantial portion of the output of these three projects is earmarked for export markets with the risk of volatile prices, the cost of capital, in theory, could be as high as that for a merchant generator; i.e., one which has limited access to long-term PPAs as hedges. This position is partially offset by access to a domestic retail hedge provided by provincial load. Taking both these factors into account, we have assumed that the projects are financed using 70 percent debt at 4.08 percent $^{29}$ and 30 percent equity at 7.58 percent. The cost of debt was based on the yield of 30-year Canadian A-rated corporate bonds, while the cost of equity was calculated using the capital asset pricing model and based on Canadian power sector comparators. ${ }^{30} \mathrm{We}$ assume a tax rate of 0 percent, given that $\mathrm{BC}$ Hydro, Manitoba Hydro and Nalcor Energy are exempted from paying federal and provincial taxes. ${ }^{31}$ The cost of capital was calculated as 5.13 percent. Details of the methodology are described in online Appendix 1.
Fixed and variable OEM costs: We used the US Energy Information Administration's (EIA) 2018 Annual Energy Outlook (AEO) estimates for fixed and variable operation and maintenance $(\mathrm{O} \& \mathrm{M})$ costs of a new 500-MW hydropower project with a 2021 in-service year and located in the US northwest. This resulted in $\$ 50.70 / \mathrm{kW} /$ year in fixed costs and $\$ 1.68 / \mathrm{kWh}$ in variable O\&M costs. ${ }^{32}$ These estimates are consistent with ranges provided by the World Bank's International Finance Corporation, which include the major equipment replacement that would be required during the lifespan of hydropower facilities. ${ }^{33}$

Output: Assumptions for the output of each plant are shown in Figure 1.

Results: Using the assumptions above, we developed a levelized cost for each of the plants, based solely on their go-forward costs. The outcome is as follows and is presented in more detail in online Appendix 2:

Site C: \$100.41/MWh;

Keeyask: \$64.89/MWh; and Muskrat Falls: \$59.25/MWh.

29 It is not appropriate to use the cost of public debt as the basis for calculating the appropriate discount rate. The province is effectively investing on the behalf of taxpayers in an enterprise that is more risky than the province's sovereign debt. Assuming 100-percent debt financing at the province's cost of funds would suggest that investing in a large-scale hydro project was no more risky than investing in sovereign debt, which is clearly not the case. For example, the Trans Mountain Pipeline project did not become less risky after it was acquired by the federal government, suggesting that assigning a lower cost of capital due to public ownership would be inappropriate in valuing it.

30 For the cost of debt, we took the average coupon rate of 30-year, A-rated corporate debt bonds issued by Canadian companies since January 1, 2017.

31 In lieu of federal and provincial income tax exemptions, the three Crown corporations make payments to provincial governments in the form of water rentals, capital taxes, debt-guarantee fees and other taxes or grants. In 2019, BC Hydro, Manitoba Hydro and Nalcor Energy are forecasted to make provincial payments of $\$ 433$ million, $\$ 589$ million and $\$ 8.2$ million respectively. These amounts represent 12.2 percent, 19.3 percent and 0.3 percent of projected gross revenues. See Manitoba Hydro. PUB-MFR-44. February 1, 2018. p.3; BC Hydro. Fiscal 2017 to Fiscal 2019 - Revenue Requirements Applications. August 17, 2016. p.80 \& 182; Newfoundland and Labrador Hydro. 2017 General Rate Application. July 28, 2017. p.206.

$32 \mathrm{AEO}$ cost estimates were converted to Canadian dollars at a rate of $0.79 \mathrm{USD}=1.00 \mathrm{CAD}$.

33 World Bank Group - International Finance Corporation. Hydroelectric Power - A Guide for Developers and Investors. February 2015. 


\section{THESE PROJECTS ARE UNECONOMIC BY SEVERAL METRICS}

\section{Replacement natural gas fired capacity is cheaper}

To explore whether the decision to continue construction on the three projects is in the public interest, we considered the costs of alternatives. First, we considered the levelized cost of building a combined cycle gas turbine ("CCGT") in each province. ${ }^{34}$ In addition to the above key assumption categories, we also incorporated the cancellation costs of the current hydro projects, as well as natural gas plant costs and carbon costs. For comparison, we also delayed the in-service date of the replacement capacity to be consistent with identified needs, discounted to the present using the previously established cost of capital.

Capital costs: We based capital costs on estimates from the US National Renewable Energy Laboratory's 2017 Annual Technology Baseline and the Alberta Electric System Operator's 2017 Proposed Gross Cost of New Entry \& Net Cost of New Entry Calculation Approach report. These sources provide a range of overnight capital cost estimates from $\$ 1,270 / \mathrm{kW}$ to $\$ 1,950 / \mathrm{kW}$. While this range may be reasonably applied to $\mathrm{BC}$ and Manitoba, the development of natural gas infrastructure in Newfoundland and Labrador would be required in addition to the cost of a new CCGT. It is not necessary to include transmission costs since a new gas-fired resource can be situated close to existing infrastructure. (A high-level geographical analysis suggests that at least 1,000 kilometres of natural gas pipelines are located within 25 kilometres of transmission lines in $\mathrm{BC}$ and Manitoba.)

Heat rate: We assumed a heat rate (the amount of fuel burned per unit of output) of $6,300 \mathrm{Btu} / \mathrm{kWh}$, consistent with the performance of the reference CCGT plant in a recent study by PJM, a regional transmission body for 13 US states, and the US EIA 2018 Annual Energy Outlook. ${ }^{35,36}$

Amortization: We used a 20-year capital recovery period for CCGTs. This is consistent with the capacity market assumptions of PJM and ISO New England, another regional transmission network. Furthermore, this time-frame is also consistent with North American experience regarding the average CCGT retirement age, which is 21 years. While our shorter assumed lifespan suggests earlier replacement than for a hydro station, we do not believe that the levelized replacement cost at that time would be significantly higher than that assumed for the first 20 years, given that technological improvements and existing site benefits can be expected to offset some of the impact of inflation.

Cost of capital: We utilized the same capital structure and cost of capital for the CCGTs as for the hydro projects. ${ }^{37}$ The projects would face the same counterparty risks, and while natural gas plants face commodity price risk, this risk is more hedgeable than hydrology.

Fixed and variable OEM: For fixed and variable O\&M, we used the average of recent

34 While some have argued that it is impossible to site a CCGT in some of the provinces, we believe that a project undertaken with appropriate consultation and unequivocal government backing would be feasible within the required time frame.

35 PJM. Cost of New Entry - Combustion Turbines and Combined-Cycle Plants with June 1, 2022 Online Date. April 19, 2018

36 EIA. Annual Energy Outlook. 2018.

37 The idea that "private" discount rates should not be used to evaluate "public" assets built for the public gives rise to a number of poor public policy choices. Discount rates are neither public nor private; they are intended to reflect the underlying risks of the project. Hydrology risk doesn't disappear because the project is public, nor do cost overruns or market risks. Governments are investing ratepayers' and taxpayers' money, and if higher-yielding investments exist elsewhere, both groups will be better off if the government eschews lower-yielding options. 
determinations by various Independent System Operators ("ISOs") associated with the Cost of New Entry (“CONE”). This resulted in estimates of $\$ 31.3 / \mathrm{kW} /$ year in fixed costs and $\$ 5.3 / \mathrm{MWh}$ in variable $\mathrm{O} \& \mathrm{M}$ costs.

Output: For each province, we assumed that the CCGT was sized to match the output of the planned new hydro facility. ${ }^{38}$ Because the CCGT has a higher capacity factor - assumed to be 85 percent in these calculations - than the hydro it replaces, the size of the facility in each province would differ. (See Table 3.) ${ }^{39}$ Both hydroelectric and gas-fired resources provide option value. Spinning gas reserves are arguably nearly as nimble as reservoir hydro in responding to changes in demand, whereas non-spinning resources will lag by the start-up time required. Overall, the marginal difference in option value is likely to be small.

We also examine like-for-like capacity replacement if an equally sized CCGT were procured while maintaining the same expected level of output. This scenario overstates the levelized cost of CCGTs when matched for hydro capacity, as a CCGT could run at a higher capacity factor than that indicated if it simply matched the energy output of the hydro plant it replaces. Assuming a higher capacity factor would lower the overall

\begin{tabular}{|c|c|c|c|}
\hline & Site C & Keeyask & $\begin{array}{c}\text { Muskrat } \\
\text { Falls }\end{array}$ \\
\hline Hydro capacity [MW] & 1,132 & 695 & 824 \\
\hline Hydro capacity factor & $53 \%$ & $72 \%$ & $68 \%$ \\
\hline $\begin{array}{l}\text { Annual generation } \\
\text { [GWh] }\end{array}$ & 5,268 & 4,400 & 4,900 \\
\hline Gas capacity factor & $85 \%$ & $85 \%$ & $85 \%$ \\
\hline $\begin{array}{l}\text { Implied gas capacity } \\
\text { required }[\mathrm{MW}]\end{array}$ & 707 & 591 & 658 \\
\hline
\end{tabular}

LCOE for capacity matching.

Cancellation costs: To assess the costs of replacing existing hydro projects with CCGTs, we also need to include the cancellation costs of the existing projects in the calculation. To do so, we took the most recent estimated cancellation costs and levelized them over the lifetime of the cancelled plant, using the allowed returns incorporated into existing rate structures. ${ }^{40}$ Matching the amortization period of cancellation costs with the would-be lifetime of the asset maintains intergenerational equity. The levelized cancellation

38 It is inappropriate to match the plants on an installed-capacity basis. The hydro facilities do not have excess capacity. The ability to dispatch at full capacity will be dependent upon the condition of their reservoirs, which will differ annually and seasonally. For the hydro comparators to receive full capacity credit, they will need to be able to deliver their full capacity at any time on short notice. In Alberta, the Alberta Electric System Operator (AESO) assumes dispatchable hydro has an unforced capacity capability of 81 percent of its installed capacity. This is also consistent with the approach taken by North American capacity markets that derate hydroelectric resources.

39 Incremental capacity can be procured more cheaply, and is of greater value closer to the location of need. In the case of BC, Site C's capacity could be replaced at much lower cost.

40 Site $\mathrm{C}$ and Muskrat Falls cancellation costs were amortized using an approved return on rate base of 3.47 percent and 6.82 percent, respectively. Keeyask's cancellation costs were discounted using the capital cost of 5.13 percent. See BC Hydro. Fiscal 2017 to Fiscal 2019 - Revenue Requirements Applications. August 17, 2016. p.576; Newfoundland \& Labrador Board of Commissioners of Public Utilities. Order No. P.U. 49. Use of different discount rates for the regulatory asset created relative to that used for the cancelled project is appropriate because the nature of the cash flows is different. While using the weighted average cost of capital (WACC) as the basis for determining the termination costs would increase the Site $\mathrm{C}$ recovered amount by $\$ 4.99 / \mathrm{MWh}$, we do not believe that such an analysis is appropriate, given the different nature of the cash flows. Furthermore, doing so would not change the fundamental conclusions. 
costs of Site C, Keeyask and Muskrat Falls were calculated as $\$ 14.06 / \mathrm{MWh}, \$ 16.56 / \mathrm{MWh}$ and $\$ 20.65 / \mathrm{MWh}$, respectively. The calculations performed are provided in online Appendix 3. This levelized cost is added to the cost of the CCGT.

Natural gas prices: To explore the impact of natural gas prices on the LCOE, we started by taking Henry Hub gas price projections from the EIA's 2018 AEO Reference Case ${ }^{41}$ and examining the price over the 2018-2037, 20-year amortization period. Then, using the same 5.13 percent discount rate as for the CCGT itself, we determined the levelized natural gas price to be $\$ 4.97 / \mathrm{MMBtu}$ over the 20-year period. Next, we determined the three-year historical monthly locational price differentials between Henry Hub and Kingsgate for BC, Emerson for Manitoba and Iroquois Waddington for Newfoundland and Labrador. Kingsgate and Emerson traded at average discounts of $\$ 0.51$ and $\$ 0.11$ respectively, while Iroquois Waddington traded at a premium of $\$ 0.72$. These differentials were applied to the levelized gas price and are provided in greater detail in online Appendix 4. In BC, an adder of $\$ 0.38$ was included to account for the motor fuel tax. We assume that CCGT facilities connect directly to existing gas transmission networks.

Carbon costs: Carbon costs were added to the variable operating costs of the CCGT coming online in 2021, using the announced policies of the various provinces as described Table $4 .{ }^{42} \mathrm{In} \mathrm{BC}$,

\begin{tabular}{|c|c|c|c|}
\hline & BC & MB & NL \\
\hline Level of administration & Provincial & Provincial & Federal \\
\hline Carbon price [\$/tonne] & 50 & 25 & 40 \\
\hline $\begin{array}{l}\mathrm{CO} 2 \text { content of natural gas } \\
{[\mathrm{lbs} / \mathrm{MMBtu}]}\end{array}$ & 120 & 120 & 120 \\
\hline CCGT heat rate $[\mathrm{Btu} / \mathrm{kWh}]$ & 6,300 & 6,300 & 6,300 \\
\hline Carbon price adder $[\$ / M W h]$ & 17.15 & 8.58 & 13.72 \\
\hline
\end{tabular}

we used the 2021 carbon tax price of $\$ 50 /$ tonne. ${ }^{43}$ In Manitoba, we applied a carbon tax of $\$ 25 /$ tonne, which is assumed to be flat until $2022 .{ }^{44}$ Pending the announcement of a plan from Newfoundland and Labrador, the province is assumed to follow the federal carbon pricing backstop and is assigned the 2021 cost of $\$ 40 /$ tonne. ${ }^{45}$ Given the carbon content of natural gas of $120 \mathrm{lbs} / \mathrm{MMBtu}$ and the thermal efficiency of new CCGTs at 6,300 Btu/kWh, the overall carbon price additions were $\$ 17.15 / \mathrm{MWh}$ in BC, $\$ 8.58 / \mathrm{MWh}$ in Manitoba and $\$ 13.72$ / MWh in Newfoundland and Labrador. ${ }^{46,47}$ In the deferral case, we used a carbon tax of $\$ 50 /$ tonne for all three projects, the high-end of the federal carbon pricing backstop. This corresponds to a carbon price add-on of $\$ 17.15 / \mathrm{MWh}$.

41 The AEO presents prices at Henry Hub, Louisiana, which is the location generally used as the starting point for gas projections given its liquidity. Canadian gas has generally traded at a discount to Henry Hub in the recent past and is expected to do so in the future.

422021 in-service year takes into account three years of construction lead time. See EIA. Annual Energy Outlook. 2018.

43 "British Columbia's Carbon Tax." Government of British Columbia. <https://www2.gov.bc.ca/gov/content/environment/ climate-change/planning-and-action/carbon-tax>.

44 Government of Manitoba. Made-In Manitoba Climate and Green Plan. March 2018.

45 Environment and Climate Change Canada. Technical Paper on the Federal Carbon Price Backstop. May 18, 2017.

46 "How much carbon dioxide is produced when different fuels are burned?" EIA.

47 PJM. Cost of New Entry - Combustion Turbines and Combined-Cycle Plants with June 1, 2022 Online Date. April 19, 2018. 
Results: Using the assumptions above, we developed a levelized cost for each of the CCGT replacement plants:

- British Columbia: $\$ 87.60 / \mathrm{MWh} ;{ }^{48}$

- Manitoba: \$81.65/MWh; and

- Newfoundland: \$96.09/MWh.

As discussed below, while we believe replacement with a CCGT could be delayed in BC, even if immediate construction were chosen, Site $\mathrm{C}$ should still be cancelled.

\section{DELAYS IN NEED ALLOW COSTS TO BE DEFERRED}

Further analysis of CCGT deferral shows that Keeyask should be cancelled as well. The economics of cancellation are further enhanced when taking into account the ability to build replacements only as needed in sizes more consistent with need. In BC, Site $\mathrm{C}$ is not needed for domestic load until three years after current target completion, according to BC Hydro's low-load growth scenario. In Manitoba, Keeyask is not needed for 13 years after current target completion. ${ }^{49}$ Muskrat Falls, however, may be too far advanced to cancel based on relative economics.

Figure 2 shows the projected need dates and demand forecasts related to the three hydro projects.
With respect to the need for Site $\mathrm{C}$, the demand forecast in the BC Hydro Submission on the British Columbia Utilities Commission Preliminary Report already assumes load from LNG Canada, Woodfibre LNG and FortisBC Tilbury Phase 2 materializes.

Results: Taking the projected need dates into account, we determined the discounted LCOE of a replacement CCGT for comparison purposes. We did this by projecting the LCOE of the replacement CCGT for the year of projected need, assuming construction commences three years in advance and then discounted that number to the present, using the CCGT discount rate. The outcomes for the energy replacement and capacity replacement scenarios are in Table 5.

As Figure 3 below shows, when replacement of cancelled capacity is deferred, ratepayers receive greater benefit from cancelling both Site $\mathrm{C}$ and Keeyask, in both the energy and capacity-matched scenarios We emphasize again that the capacitymatched scenario overstates the LCOE, as lower capacity factors are assumed to match the expected output from the hydro projects. ${ }^{50,51}$

It is important to emphasize the value of optionality, which comes with the ability to build in smaller unit sizes. The North American power sector is changing rapidly: demand is slowing or

48 Site C's completion could be justifiable under a carbon price of more than $\$ 100 /$ tonne. However, higher carbon prices also make any of the more granular zero-emission resources a more economic choice.

49 In the September 2016 Boston Consulting Group review of Bipole III, Keeyask and Tie-Line, Manitoba Hydro stated the earliest consistent need for new generation would be 2027 and noted the need may not arise until as late as 2034. See The Boston Consulting Group. Review of Bipole III, Keeyask, and Tie-Line Projects, p. 4. September 19, 2016.

50 While we believe the use of a lower WACC is inappropriate, WACC sensitivities do not dramatically change the conclusions. Using a WACC of 4.13 percent and holding other input assumptions constant, Site $\mathrm{C}$ is still uneconomic. While its LCOE falls from $\$ 100.41 / \mathrm{MWh}$ to $\$ 86.29 / \mathrm{MWh}$, the LCOE of its cancellation and deferred energy replacement is $\$ 81.40 / \mathrm{MWh}$. However, in this scenario Keeyask is economic as its LCOE falls from $\$ 64.89 / \mathrm{MWh}$ to $\$ 56.02 / \mathrm{MWh}$, as compared to the LCOE of its cancellation and energy replacement of $\$ 60.13 / \mathrm{MWh}$.

51 To examine like-for-like capacity replacement, procuring an equally sized CCGT in lieu of hydro at the same capacity factors still shows ratepayers receive greater benefit from cancelling both Site C and Keeyask. Specifically, deferred replacement results showed: Site C replacement LCOE of \$92.98/MWh, below its completion LCOE of $\$ 100.41 / \mathrm{MWh}$, and Keeyask replacement LCOE of $\$ 62.60 / \mathrm{MWh}$, below its completion LCOE of \$64.89/MWh. An even more costeffective approach to match both capacity and energy would be to build a mix of CCGT and open-cycle gas turbines. 


\section{Figure 2: Projected Need Dates and Demand Forecasts}
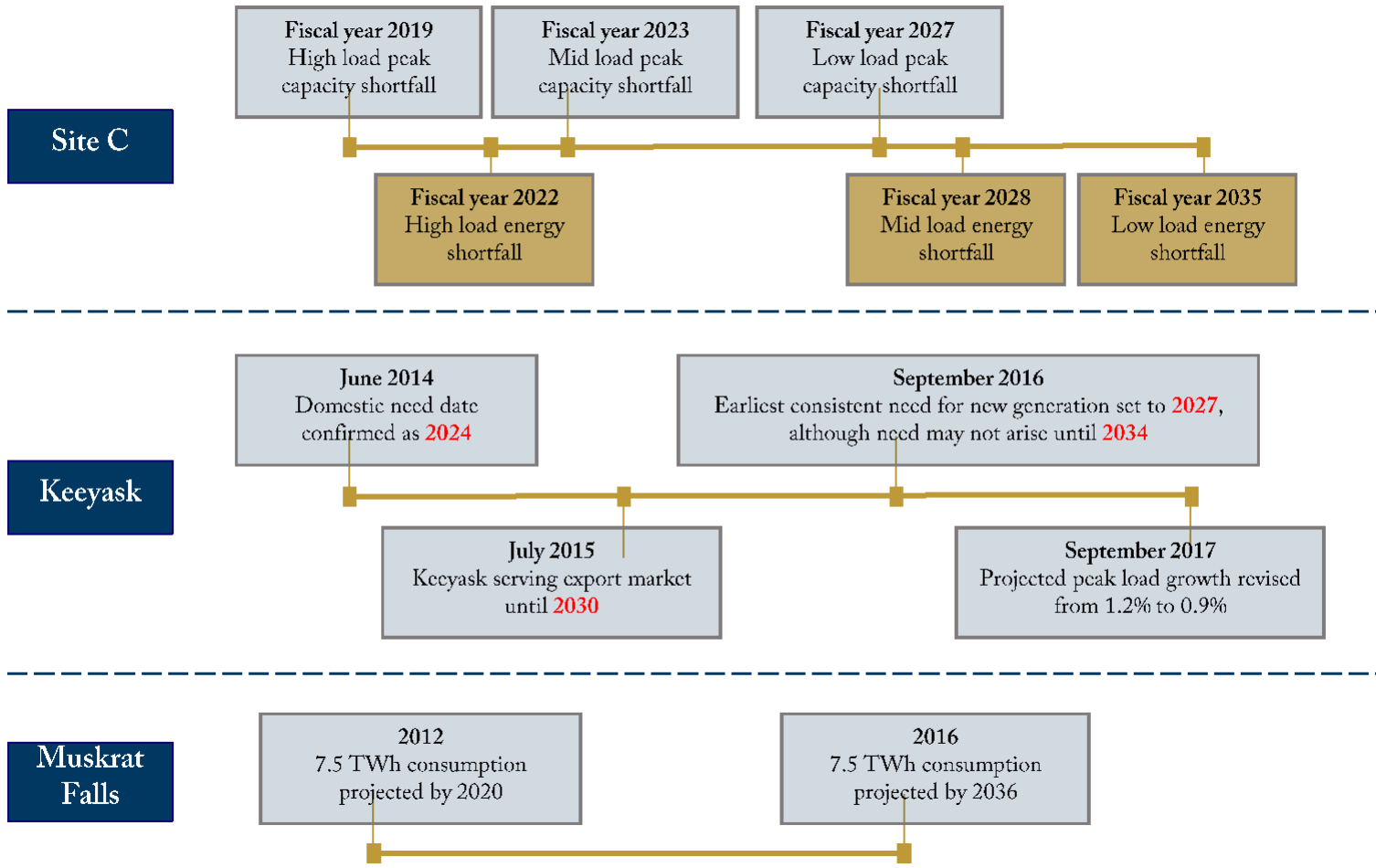

Sources: BC Hydro. BC Hydro Reply Submission. 2017; Manitoba Hydro. PUB/GSS-GSM-KAP-7; MPUB. NFAT. June 2014; MPUB. Order No. 73/15; Boston Consulting Group. Review of Bipole III, Keeyask and Tie-Line Projects; Nalcor Energy. Muskrat Falls Project Update. June 24, 2016.

\section{Table 5: Deferred Energy and Capacity Replacement LCOEs}

\begin{tabular}{|c|c|c|c|c|}
\hline \multirow{2}{*}{ Province } & \multicolumn{2}{|c|}{ Energy Replacement } & \multicolumn{2}{|c|}{ Capacity Replacement } \\
\hline & $\mathrm{LCOE}[\mathrm{C} \$ / \mathrm{MWh}]$ & Capacity factor & LCOE $[\mathrm{C} \$ / \mathrm{MWh}]$ & Capacity factor \\
\hline British Columbia & 81.40 & $85 \%$ & 92.98 & $53 \%$ \\
\hline Manitoba & 60.13 & $85 \%$ & 62.60 & $72 \%$ \\
\hline $\begin{array}{l}\text { Newfoundland \& } \\
\text { Labrador }\end{array}$ & 92.80 & $85 \%$ & 97.60 & $68 \%$ \\
\hline
\end{tabular}




\section{Figure 3: Comparison of Hydro and Deferred CCGT LCOE}

$\$ / \mathrm{MWh}$

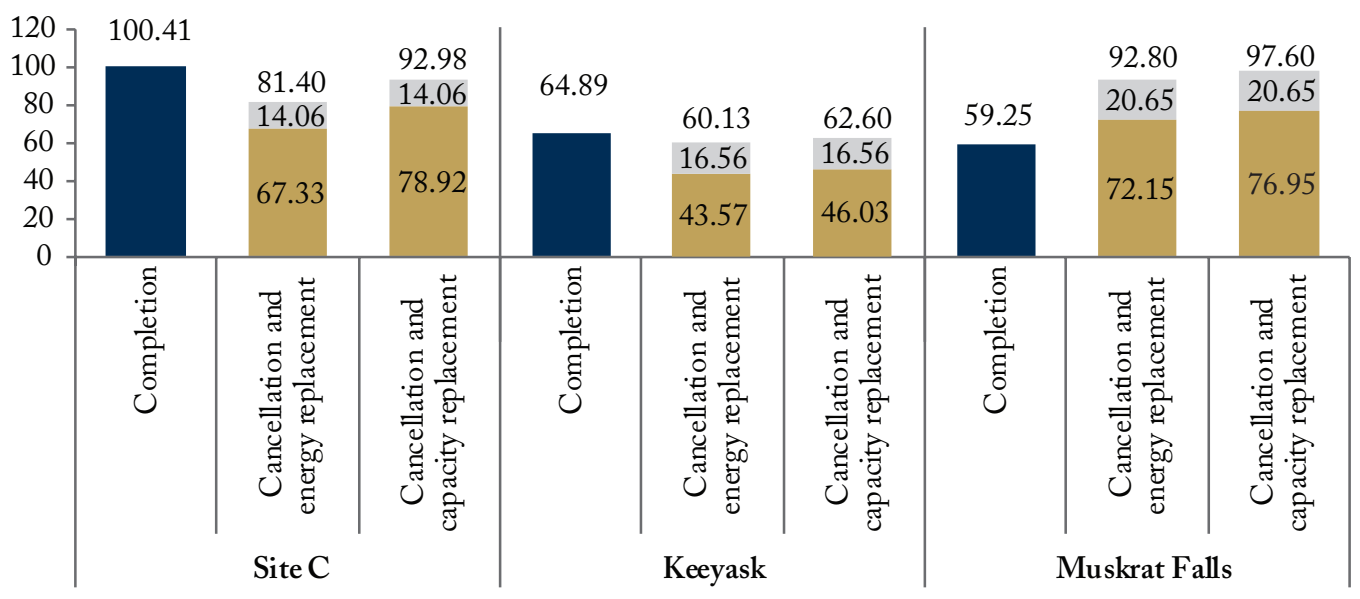

- Hydro LCOE $₫$ CCGT LCOE $\backsim$ Levelized cancellation costs

negative, behind the meter production and storage is gradually becoming more economic. At the same time, decentralized power grids are becoming more feasible. Large-scale, centralized, long leadtime investments like hydro stations run the risk of becoming stranded assets (assets which are no longer able to recover their costs) before they are even brought online, depending on the pace of technological change. Having the option to build something smaller and later means that provincial utilities can better tailor future investments to updated power sector dynamics, while being able to take advantage of intervening technological changes. Furthermore, the ability to spread these investments across the grid may enhance reliability and resiliency.

\section{EXAMINATION OF SENSITIVITIES REINFORCES THE CONCLUSIONS}

While it is important to recognize that each of the variables has a range of plausible outcomes, we believe that the best way to explore this span is to assess how the variables interact with one another. To assess the sensitivity of assumptions to changes in combinations of key variables, we examined the outcomes using Monte Carlo analysis, a mathematical technique that generates random variables on the basis of a probability distribution to be used for modelling risk or uncertainty. Within determined input ranges, 1,000 trials were drawn following a normal distribution. For each trial, we compared the LCOEs of completing the hydro project to the LCOEs of deferred gas replacement combined with the levelized cost of cancellation. 


\section{Figure 4: Power Sector Trends Making Central Stations Less Valuable}

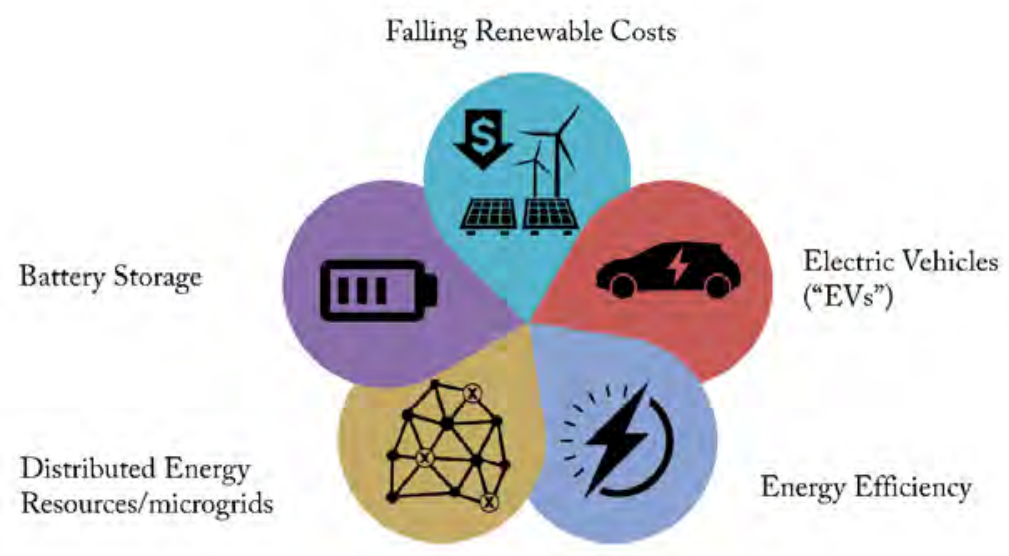

Note: Payroll taxes are not presented since their profiles are similar to workers'social contributions. The profiles for other taxes are identical between male and females aged 18 and over.

Source: Authors' calculations, using Statistics Canada's SPSD/M and data sources in Figure 2.

For all three projects, input ranges were determined for the weighted average capital cost (WACC), levelized gas price, carbon cost and remaining completion costs. The input ranges for each variable are as follows:

- WACC: We tested values ranging from 4.13 percent to 6.13 percent within 100 basis points of the calculated WACC of 5.13 percent. LCOE comparisons in each trial apply the same WACC to both alternatives (project completion versus project replacement).

- Natural gas prices: In terms of the levelized gas price, we tested values ranging from $\$ 3.85 /$ MMBtu to $\$ 7.70 / \mathrm{MMB}$ tu based on the high and low-case EIA forecast from its 2018 AEO.

- Carbon costs: For carbon costs, we tested values ranging from $\$ 20$ per tonne to $\$ 100$ per tonne to include ranges from provincial and federal carbon pricing plans, and a significant margin.

- Completion costs: We examined the impact of variation in the completion capital costs for the three hydro projects. We tested bounds of +10 percent and -5 percent for each project, resulting in a $\$ 8.1$ billion to $\$ 9.4$ billion range for Site $\mathrm{C}, \$ 4.3$ billion to $\$ 5.0$ billion for Keeyask and $\$ 4.2$ billion to $\$ 4.9$ billion for Muskrat Falls.

As seen in Figure 5, cancellation and deferred gas replacement was cheaper in 96 percent of Monte Carlo trials conducted for Site C, 61 percent of trials conducted for Keeyask and 0 percent of trials conducted for Muskrat Falls.

\section{PRICES IN EXPORT MARKETS ARE EXPECTED TO BE DEPRESSED}

Cross-border electricity flows between Canada and the US are almost as old as the North American electricity grid, with the opening of the first transmission line between the two countries in 1909. ${ }^{52}$ These flows are taken for granted to such an extent that they are used to justify investment 


\section{Figure 5: Results of Monte Carlo Analysis of Sensitivities}

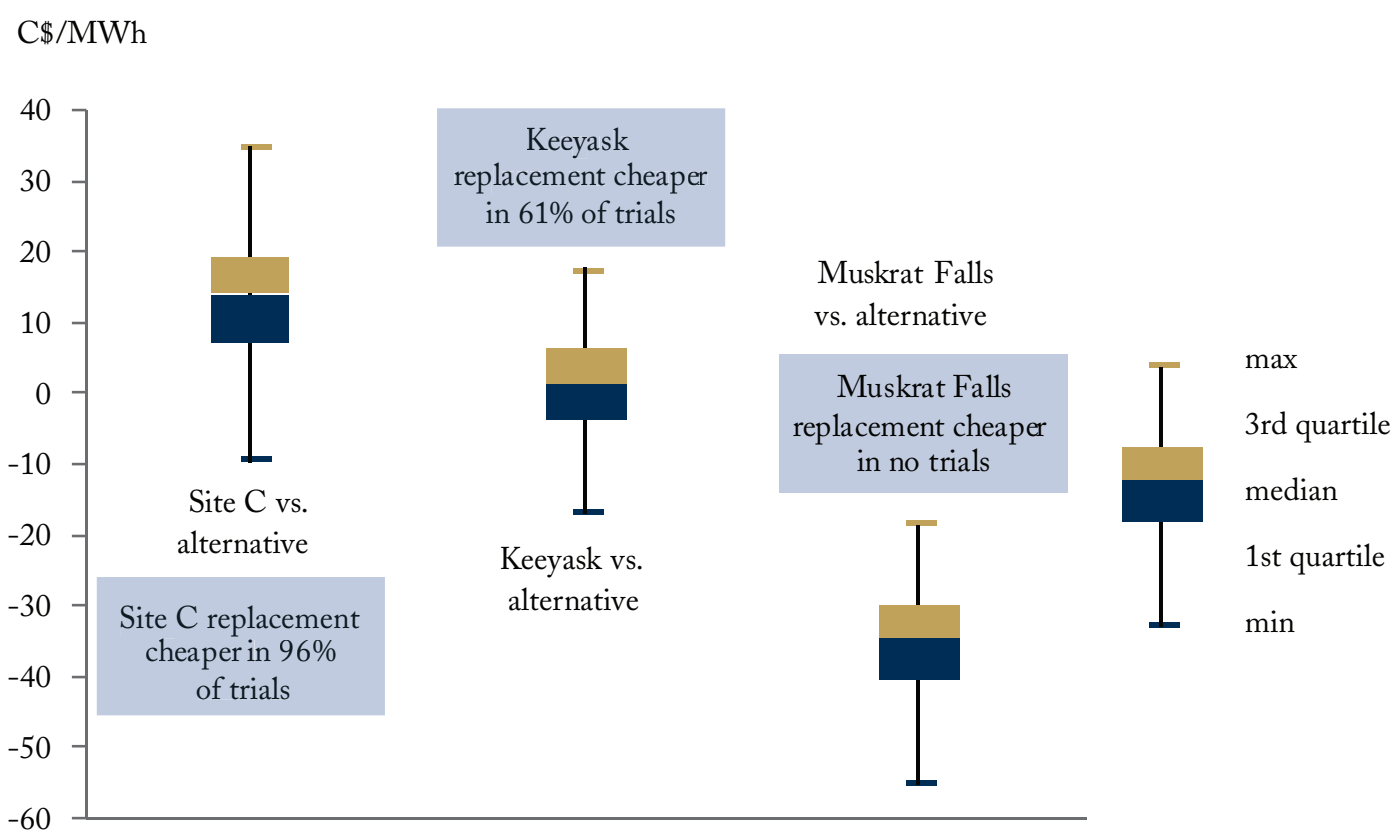

Source: Authors' calculations.

decisions in new hydroelectric facilities in Canada. However, North American power markets are evolving rapidly: load growth has fallen, cheap natural gas has reduced wholesale power prices substantially and targeted local renewables incentives have increased US power supplies.

As a result, US export markets are likely to be significantly less lucrative in the future..$^{53}$ This is a function both of the depressed price of natural gas - which, as discussed above, is not expected to increase dramatically over the forecast horizon - and of significant state (and expiring Federal) initiatives to encourage development of domestic large-scale renewable-energy assets.

As Figure 6 shows, combined energy and capacity prices ${ }^{54}$ in the target regions are expected to be below the levelized cost to complete Site C. While prices in export markets are expected to increase over the forecast period, they are not expected to reach historic levels. Essentially, this

53 Declining export profits are evident today. BC Hydro's \$643 million in 2016 gross electricity export revenues was its lowest in over a decade with an average price of $\$ 43.65 / \mathrm{MWh}$. This contrasts with $\$ 2.29$ billion in 2009 at an average price of $\$ 70.45 / \mathrm{MWh}$. Manitoba Hydro earned $\$ 460$ million in gross electricity export revenues in 2017,61 percent of the $\$ 750$ million earned in 2005.

54 Capacity prices are converted to $\$ / M W h$ by dividing them by the total number of hours in a year. This process is necessary to allow for calculation of capacity revenues to resources that are assumed to be derated. 


\section{Figure 6: Project LCOE and Export Market Combined Energy and Capacity Price Forecast} Comparison
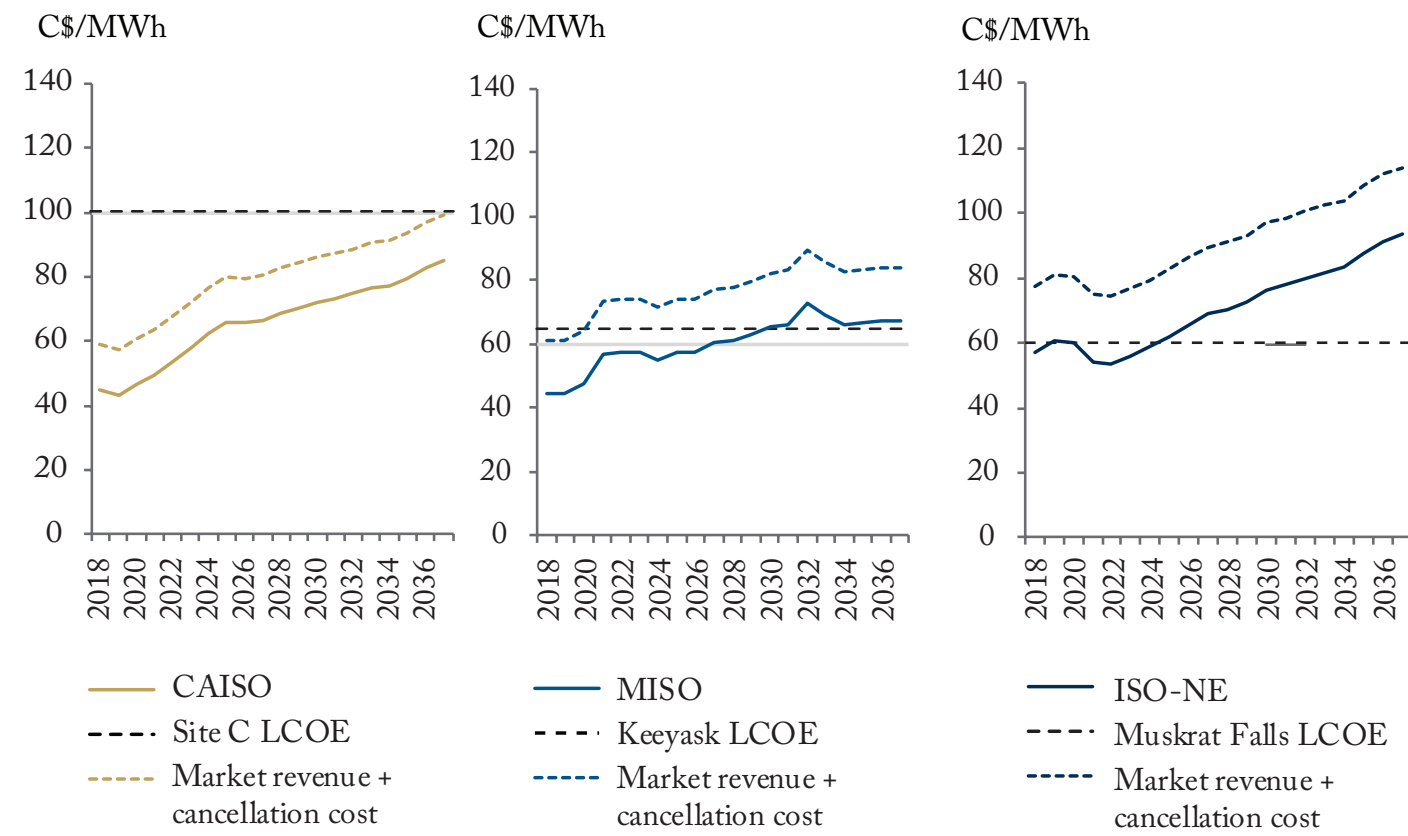

Note: Market forecasts account for expected coal and natural gas retirements in their respective markets.

Source: LEI Continuous Modelling Initiative 2017 Q2 reports.

means that when exporting electricity, Canadian ratepayers will be subsidizing US consumption, rather than profiting from it. ${ }^{55}$

Furthermore, Figure 5 assumes that new Canadian hydro facilities are granted full production-weighted capacity credit. But capacity is generally based on deliverability. Transmission deliverability needs to be available for the full amount of claimed capacity, performance penalties may apply and capacity credits may be derated. ${ }^{56}$

Indeed, in the cases of Site $\mathrm{C}$ and Keeyask, adding the levelized cancellation costs to the export market price were sufficient transmission available, would make it cheaper (even accounting for transmission costs) for Canadian utilities to cancel the specified projects and import from the US. For example, adding Site C's cancellation cost of $\$ 14.06 / \mathrm{MWh}$ to the levelized price of energy and capacity from the California Independent System Operator (CAISO) is cheaper than the LCOE of finishing Site $\mathrm{C}$ until 2037. Importing allows for an even more granular approach to addressing future needs and, given the much larger market areas to which the provinces are linked, it offers a wide

55 This is already happening in Ontario, which has provided more than $\$ 57.5$ million in benefits to US ratepayers since 2010 as a result of surplus baseload generation. See IESO. Hourly intertie schedule and flow data. 2010-2017; IESO. Hourly Ontario Energy Price data. 2010-2017.

56 While export contracts are in place to cover a portion of the output of the new projects, it is important to note that these contracts cover only a portion of the new projects' useful lives and could be profitably unwound by meeting the obligations with cheaper qualifying local replacement power. 


\section{Figure 7: Timeline of Energy Storage Procurements in California}

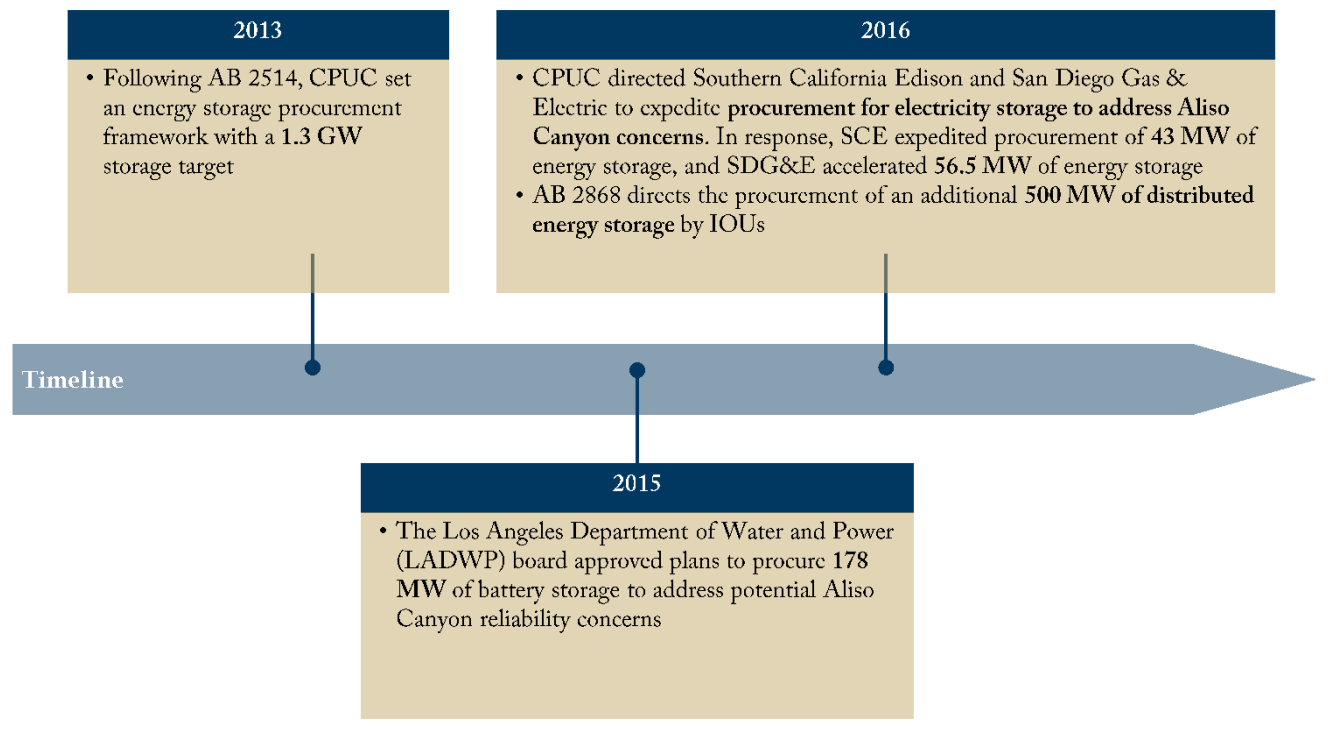

Source: CEC. Tracking Progress - Energy storage. November 2017.

diversity (including zero-emission sources) of supply.

\section{CALIFORNIA WON'T SAVE US}

In the case of Site $\mathrm{C}$, some have argued that the unique characteristics of the California electricity market will help to justify its construction. In fact, the opposite may be true. Those unique aspects make it less likely that California will need energy or capacity from Site C. First, California policies targeting increased renewables have resulted in an oversupply of power over many hours of the day. Indeed, California's motivation for launching the Western Energy Imbalance Market is to export, not to import. In a presentation before the California Energy Commission, CAISO noted that the
Western Energy Imbalance Market helped avoid curtailment of renewables, by 586,277 MWh as of the first quarter of 2018..$^{57,58}$ Second, as Figure 7 shows, California is aggressively contracting for in-state storage resources to balance existing and new renewables. Third, continued growth in behind-the-meter renewable energy resources and substantial energy-efficiency efforts have resulted in reduced load growth. Recent California Energy Commission projections for peak demand are increasing only 0.9 percent per year. ${ }^{59}$ Furthermore, a review of relevant California dockets shows no meaningful reference to Site C. Taken together, these factors suggest that the California market may not be nearly as robust an export destination as $\mathrm{BC}$ planners would wish it to be.

57 CAISO. IEPR Workshop - Renewable Integration. May 12, 2017.

58 CAISO. Western EIM Benefits Report - First Quarter 2018. April 20, 2018.

59 California Energy Commission. The California Energy Demand 2018-2030 Revised Forecast. January 22, 2018. 


\section{Figure 8: Levelized Cost of Wind Compared to Gas Turbines and Hydro}

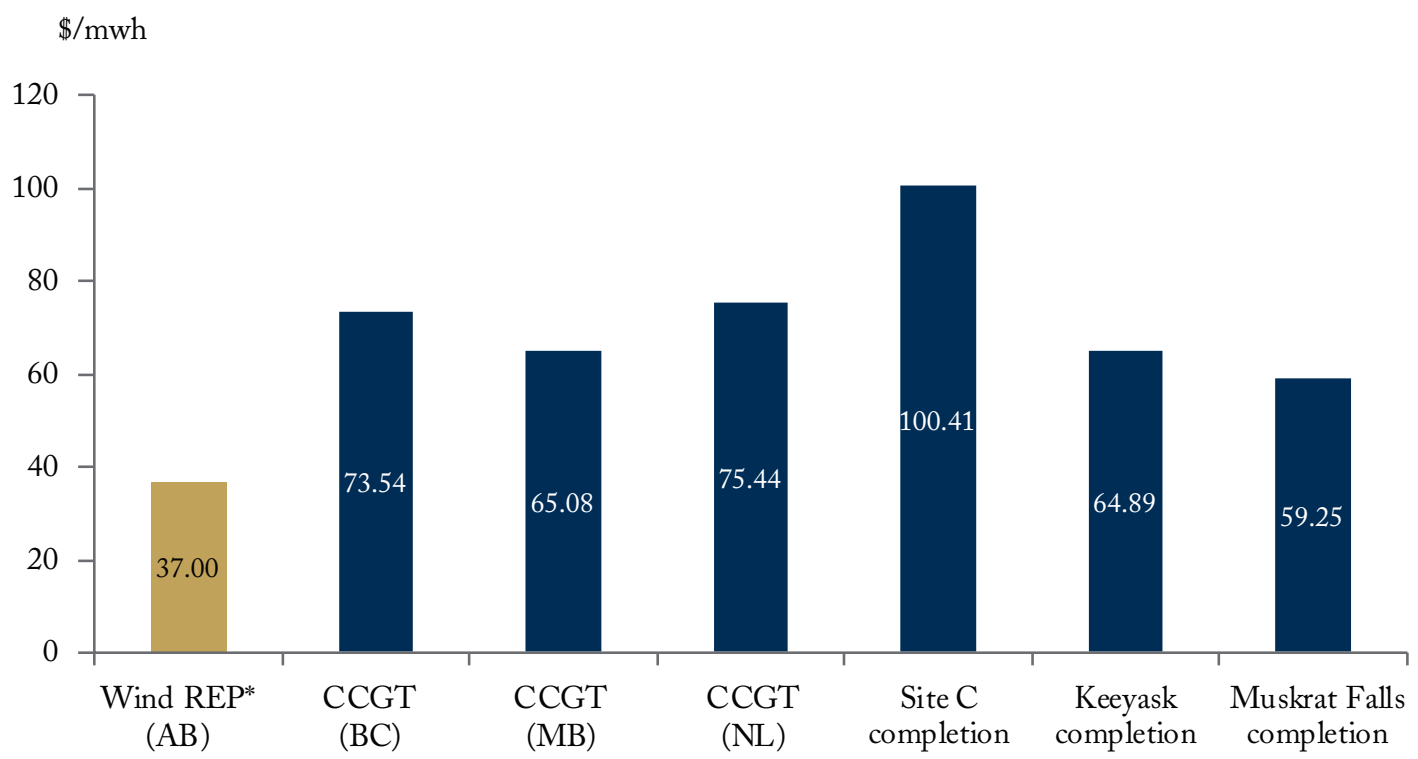

* Renewable Energy Program.

Source: Authors' calculations.

THERE ARE CHEAPER WAYS TO MEET EMISSIONS GOALS

Comparison of large Canadian hydro completion costs to the CCGT alternatives has been criticized on the basis that, while CCGTs would pay carbon costs, they would nonetheless have actual emissions that would make it more difficult for Canada to meet its Paris climate agreement commitments. While there are other ways to accomplish this objective when building CCGTs (for example, committing to a verified offset program), ${ }^{60}$ building large-scale hydro is not the only way to obtain zero emissions power. Falling costs of large-scale wind power, coupled with more efficient wind-power storage, are both potentially more cost effective and, like CCGTs, can be deferred until need is apparent and sized accordingly. In fact, the first round of the Alberta government's Renewable Energy Program procured approximately $600 \mathrm{MW}$ of wind power under 20-year contracts at $\$ 37 / \mathrm{MWh}$, well below the cost to complete any of the hydro stations examined, even when considering the need to balance the associated intermittency. ${ }^{61}$ Deferring investment

60 Article 6 of the Paris Agreement permits applying internationally transferred mitigation outcomes toward nationally determined contributions. These outcomes are voluntary and are to be authorized by the participating parties. See UNFCCC. Paris Agreement. November 2015.

61 Contract recipients receive an indexed renewable energy credit that represents the difference between the clearing price of \$37/MWh and the AESO market pool price. As such, contract recipients receive true-up payments from the government when pool prices are low and pay the surplus when pool prices are high. See "Renewable Electricity Program." AESO. < https://www.aeso.ca/market/renewable-electricity-program/> 
also allows for technological improvements and cost reductions. In its 2017 report, the International Renewable Energy Agency predicted that the installed costs of battery storage systems could fall by 50 percent to 66 percent by $2030 .^{62}$ As such, the combination of wind and storage may be cheaper by the time it is actually needed.

\section{LIMITING THE ROLE OF INDEPENDENT REGULATORS RESULTS IN FALSE EXPEDIENCY}

In each of the three provinces, limited regulatory authority undermined reviews of their respective megaprojects. Large hydroelectric generation investments on the scale of Site C, Keeyask and Muskrat Falls, which amount to multi-billion dollar undertakings, must be vetted with corresponding due diligence.

\section{Site C: British Columbia Utilities Commission}

In British Columbia, the Utilities Commission Act ("UCA") gives the BC Utilities Commission (BCUC) powers to regulate public utilities. Under Section 45 of the UCA, in most instances, construction of new electricity generating facilities cannot begin without the Commission issuing a Certificate of Public Convenience and Necessity, which is granted if the proposed facility is "necessary for the public convenience and properly conserves the public interest." ${ }^{163}$ Despite this provision, Site $\mathrm{C}$ was exempted from BCUC scrutiny under the province's Clean Energy Act. ${ }^{64}$ Energy Minister Bill Bennett justified this decision stating: "The reason why we didn't send it to the BCUC is back when the Clean Energy Act was passed (2010), there was a decision made that if government was to build Site C, it would be a monumental decision in terms of energy policy that only duly elected officials have a right to make, as opposed to an organization like the BCUC that is made up of bureaucrats and lawyers." ${ }^{25}$

But monumental projects are precisely those that require additional scrutiny. Instead, Site $\mathrm{C}$ was subject to a compressed nine-month long environmental assessment conducted by a large team reporting to a three-person Joint Review Panel. This panel recommended that the project be referred to the BCUC, but this did not occur. ${ }^{66}$ BCUC's involvement came after the decision to go ahead was made. Construction began in 2015, whereas the BCUC review report was released in November 2017.

\section{Muskrat Falls: Newfoundland and Labrador Board of Commissioners of Public Utilities}

Under Nerwfoundland and Labrador's Public Utilities Act, RSNL-1990: "A public utility shall not proceed with the construction, purchase or lease of improvements or additions to its property where (a) the cost of the construction or purchase is in excess of $\$ 50,000$; or (b) the cost of the lease is in excess

62 IRENA. Electricity storage and renewables: Costs and markets to 2030. October 2017.

63 British Columbia Utilities Commission. Inquiry Respecting Site C - Final Report to the Government of British Columbia. November 1, 2017. (p. 12)

64 Legislature of British Columbia. Clean Energy Act-Chapter 22. Section 7, Subsection 1 (Exempt projects, programs, contracts and expenditures).

65 "Site C Dam will not be diverted to B.C. Utilities Commission" Alaska Highway Nerws. 2015. < http://www. alaskahighwaynews.ca/site-c/site-c-dam-will-not-be-diverted-to-b-c-utilities-commission-1.2076979> Bennet maligns the capabilities and purpose of an independent regulator; massive public investment undertakings putting ratepayer money at risk need to be scrutinized outside of the political sphere by experts who can opine on need and alternatives in a fact-based process.

66 University of British Columbia. Regulatory Process for the Site C Project. May 2016. 
of $\$ 5,000$ in a year of the lease, without the prior approval of the board." 67

Following an environmental assessment, the Lower Churchill Hydroelectric Generation Project was reviewed by a four-person Newfoundland and Labrador Board of Commissioners of Public Utilities panel to address whether the Muskrat Falls generation facility and the Labrador-Island Link transmission line represented the least-cost option for the supply of power to Island Interconnected customers over the 2011-2067 period when compared to the isolated Island development scenario. The review took place over a nine-month period; "[t]he Board's report on the Reference Question was initially required to be provided to the Minister of Natural Resources by December 30, 2011. This date was later extended to March 31, 2012 as a result of delays in receipt of critical documentation from Nalcor. This significantly impacted the Board's process and ability to answer the Reference Question as key procedural steps had to be changed or eliminated in order to meet the March 31, 2012 deadline. ${ }^{\text {"68 }}$

Subsequently, the Newfoundland and Labrador Board of Commissioners of Public Utilities conducted a review of the Muskrat Falls project in 2012. In the proceeding's final report to government, the Board notes the woeful lack of due diligence regarding budget-impacting components of the project, stating: "There were gaps in Nalcor's information and analysis [in its decision to approve the development scenario and to commence detailed design], including: i) AC integration studies were not done; ii) probabilistic reliability studies to compare the two options were not done; iii) there is uncertainty with respect to adherence to NERC standards, and iv) the design return period for the HVDC overland transmission line is not in accordance with accepted standards and best practice. " provided by Nalcor to the public utilities board was approximately two years old and was not updated during the review.

\section{Keeyask: Manitoba Public Utilities Board}

Under the Manitoba Crown Corporations Public Review and Accountability and Consequential Amendments Act, "No change in rates for services shall be made and no new rates for services shall be introduced without the approval of The Public Utilities Board." 70 No authority, explicit or implied, requiring the review and approval of capital expenditure is granted to the Manitoba Public Utilities Board (MPUB), but inclusion of such expenditure in rates is not guaranteed. However, the Manitoba government issued an Order-in-Council providing the MPUB with special authority to access information on Manitoba Hydro's financial health and capital expenditure plans during the 2017/18 General Rate Application process. ${ }^{71}$

\section{WHERE DO WE GO FROM HERE?}

\section{It's Not Too Late to Reconsider}

For projects like Site $\mathrm{C}$ and Keeyask, it is not too late to cancel. The sooner provinces face reality and begin negotiating reasonable cancellation programs, the better off ratepayers will be. Similar analyses may be applied to decisions like nuclear refurbishment. Provinces should consider hiring skilled negotiators to review all existing contracts

67 Legislature of Newfoundland and Labrador. Public Utilities Act. 1990.

68 Newfoundland and Labrador Board of Commissioners of Public Utilities. Review of two generation expansion options for the least-cost supply of power to island interconnected customers for the period 2011-2067. March 30, 2012. (p. 4)

69 Newfoundland and Labrador Board of Commissioners of Public Utilities. Review of two generation expansion options for the least-cost supply of power to island interconnected customers for the period 2011-2067. March 30, 2012. (p. 6)

70 Legislature of Manitoba. The Crown Corporations Public Review and Accountability and Consequential Amendments Act. 1988.

71 Government of Manitoba. Order in Council. April 5, 2017. 
and develop a pathway toward minimizing cancellation costs, identifying ways to recover value and exploring means of appropriately compensating key stakeholders such as First Nations. Given the lack of near term domestic need, provinces can focus on efficient project closure before exploring how best to meet long-term needs. However, the answer to that question almost certainly incorporates a portfolio of smaller-scale, shorter lead time, clean-resources dispersed geographically and temporally procured under a mix of ownership structures.

\section{Institutional Independence Must be Strengthened}

The nature of our parliamentary system means that governments with strong majorities can make quick changes to laws, restructuring regulatory institutions, changing their mandates, and enhancing or diminishing their powers. Regulators are often bypassed, meaning that large investment decisions can be undertaken based on the political whims of the moment. It is critical that Canadian provinces develop a commitment to well-resourced, independent and empowered regulators. Processes for review of large-scale publicly owned projects should not be ad hoc, nor should provinciallyowned entities be given a free pass from review. Commitments to independent review increase as past projects are shown to be uneconomic. However, memories fade, the lure of a new ribboncutting becomes too much and regulatory bodies are bypassed again. To the extent possible, a commitment to stronger, independent regulation should be embedded in legislation, along with a set of procedures that make it more difficult to circumvent that promise in future laws.

\section{Greater private sector participation may increase discipline}

Privatization is not a panacea; it needs to be accompanied by clear regulation and sound market rules. However, private sector involvement comes in a wide range of forms; indeed, Canada has been a leader in forms of inclusive privatization, which enable participation by pension funds, First Nations, and unions in the newly private entity. Large hydro sites could be auctioned or leased to private-public partnerships to improve price discovery and risk allocation, for example. In the Canadian context, where Crown corporations using ratepayer money become instruments of public policy, increasing private sector involvement can help prevent provinces from making costly mistakes.

Canadian provinces have significant capital locked up in mature industries in which private investment is common elsewhere in the world. Ironically, Canadian pension funds are among the leading investors in such assets outside of Canada. Provincial funds that are currently devoted to the utility sector can be recycled into activities where government investment provides a greater catalyst to growth and private investment is less available. Criticisms of recent privatizations, such as that of Hydro One, almost always miss the point that governments have funding constraints in other infrastructure areas that have higher social returns.

Even if the independence of Canadian regulatory institutions were strengthened, governments are notoriously bad at regulating themselves. Increasing private sector involvement in turn increases the independence of the regulator, because the regulator's rulings have greater consequences shareholders losing money tend to put pressure on their boards to change their behaviour. Crown corporations losing money (or not making as much as they should) may be tolerated for a much longer period of time. Private entities would have been less likely to continue to greenlight further expenditures as cost overruns soared and market conditions deteriorated. Regulators would also have been better able to order reviews of imprudent investments by private utilities. For projects that cannot be cancelled, or are past the point of economically doing so, the respective provincial 
governments should at least explore the value that the private sector would put on the project going forward to determine whether any new risk-sharing arrangements are feasible.

\section{SHORT-TERM PAIN FOR LONG-TERM} GAIN

While the decision to cancel projects is politically difficult, clever regulatory accounting may enable more muted rate increases than those that have already been announced. For example, longer amortization of cancellation costs, coupled with avoidance of future costs, should enable demonstrable ratepayer benefits to be achieved. Provincial utilities sometimes point to current low rates as meaning that rate increases have limited impact. Yet those rate increases, when arising due to uneconomic choices, erode the competitive advantage of those provinces. This advantage is already under threat from lower US tax rates and falling US wholesale power prices as a result of low natural gas prices and substantial renewables production.

Cancelling uneconomic projects now is the right choice. Enshrining regulatory independence and private-sector participation will help shield ratepayers from future bad decisions. 


\section{REFERENCES}

Alberta Electric System Operator (AESO). 2017. "Cost of New Entry Document for Adequacy Demand Curve Working Group.” November 22.

BC Hydro. 2014. "Site C Capital Cost Estimate." 2016. "Fiscal 2017 to Fiscal 2019 - Revenue Requirements Applications.” August. . 2017a. "British Columbia Utilities Commission Preliminary Report.” October. .2017b. 'BC Hydro Reply Submission.” 2018a. "Quarterly Progress Report No. 10: F2018 Third Quarter - October 2017 to December 2017.” March 29. .2018b. "Site C Clean Energy Project Annual Progress Report No. 2.” March.

Boston Consulting Group. 2016. "Review of Bipole III, Keeyask and Tie-Line Projects." September 18.

British Columbia Utilities Commission. 2017. "Inquiry Respecting Site C: Executive Summary of the Final Report to the Government of British Columbia." November.

California Energy Commission. 2009. "Comparative costs of California Central Station Electricity Generation.” August.

November. 2017. "Tracking progress - Energy Storage." . 2018. "The California Energy Demand 2018-2030 Revised Forecast.” January 22.

California ISO. 2017. "IEPR Workshop - Renewable Integration.” May 12.

2018. "Western EIM Benefits Report First Quarter 2018.” April 20.

Canada Electricity Association. N.D. "History of electricity.” Accessed at:. <https://electricity.ca/learn/ history-of-electricity/>.

Deloitte. 2017. "British Columbia Utilities Commission - Site C Construction Review.” September.
Energy Information Administration. N.D. "How much carbon dioxide is produced when different fuels are burned?" accessed at: <https://www.eia.gov/tools/ faqs/faq.php?id=73\&t=11> .2018. "Annual Energy Outlook."

Grabowski, R., Nunes, C., and Harrington, J. 2017. "Valuation Handbook - International Guide to Cost of Capital.”July.

Government of British Columbia. N.D. "British Columbia's Carbon Tax.” Accessed at: <https:// www2.gov.bc.ca/gov/content/environment/climatechange/planning-and-action/carbon-tax> .2017a. "Tax Rates on Fuels: Motor Fuel Tax Act and Carbon Tax Act." November. .2017b. "Government will complete Site C construction, will not burden taxpayers or BC Hydro customers with previous government's debt." BC Government News. December.

Government of Manitoba. 2017. Order in Council. April 5.

Government of Newfoundland and Labrador. N.D. "Backgrounder - Quick Facts - Muskrat Falls Development Generation and Transmission.” Accessed at: <https://www.gov.nl.ca/ lowerchurchillproject/backgrounder_7.htm>. .2010. "Lower Churchill Project to Become a Reality.” Accessed at: <http://www.releases.gov.nl.ca/ releases/2010/exec/1118n06.htm>.

.2011. "Report of the Joint Review Panel Lower Churchill Hydroelectric Generation Project." August.

2012. "Formal Agreements Signed Between Nalcor Energy and Emera Inc. for Muskrat Falls Development." July 31.

International Renewable Energy Agency. 2017. "Electricity storage and renewables: Costs and markets to 2030." October. 
ISO-New England. 2018. "Forward Capacity Market Parameters." March 8.

Keeyask Hydropower Limited Partnership. 2010.

"Lower Churchill Project to Become a Reality."

Accessed at: <http://www.releases.gov.nl.ca/ releases/2010/exec/1118n06.htm>.. 2014.

"Construction Begins on Keeyask Generating

Station.” July.

.2011. “\$5.6 Billion Keeyask Generating

Station Announced.”June.

2017. "Control Budget for Keeyask

Generating Station Revised 2017.” March.

Lazard. 2017. "Lazard's Levelized Cost of Storage

Analysis - Version 3.0.” November.

Legislature of British Columbia. Clean Energy ActChapter 22.

Legislature of Manitoba. 1988. The Crown Corporations

Public Review and Accountability and Consequential Amendments Act. 1988.

Legislature of Newfoundland and Labrador. Public Utilities Act. 1990.

Manitoba Hydro. N.D. "Keeyask Generating Station.” Accessed at: <https://www.hydro.mb.ca/projects/ keeyask/index.shtml>.

.2017. "Manitoba Hydro 2017/18 \& 2018/19 General Rate Application: GSS/GSM/ MH I-4.” September.

. 2017. "Manitoba Hydro 2017/18 \& 2018/19 General Rate Application: GSS-GSM/ MH I-3a-c.” September. 2018. "Manitoba Hydro 2017/18 \& 2018/19 General Rate Application: PUB-MFR-44.” February 1.

.2018. "Manitoba Hydro 2017/18 \& 2018/19 General Rate Application: COALITION/ MH I-54.” February 1.

Manitoba Public Utilities Board. 2015. Order No. 73/15. July 24.

Nalcor Energy. N.D. "Project Overview. Muskrat Falls Generating Project." Accessed at: <https:// muskratfalls.nalcorenergy.com/project-overview/ muskrat-falls-hydroelectric-generation-facility/>.
2016. “Muskrat Falls Project Update.”July

2016. 2017. “Muskrat Falls Project Update.”June 2017. .2017. "Muskrat Falls Project Update.” September. .2018. "Muskrat Falls Project Update." November 2017. January 16. .2018. “Understanding Muskrat.” February 15. 2018. "Muskrat Falls Project, Monthly Report - February 2018.” April 20.

National Renewable Energy Laboratory. 2017 Annual Technology Baseline. August 21, 2017.

Newfoundland \& Labrador Board of Commissioners of Public Utilities. 2016. Order No. P.U. 49.

.2012. "Review of two generation expansion options for the least-cost supply of power to island interconnected customers for the period 20112067." March 30.

Newfoundland and Labrador Hydro. 2017. “2017

General Rate Application.” July 28.

Newfoundland and Labrador Regulation 101/17. 2017. "Commission of Inquiry Respecting the Muskrat Falls Project Order." November 20.

New York ISO. 2017. “Annual Update for 2018-2019

ICAP Demand Curves.” November 6.

PJM. Cost of New Entry - Combustion Turbines and Combined-Cycle Plants with June 1, 2022 Online Date. April 19, 2018.

Site C Clean Energy Project. N.D. Project Overview." Site C. Accessed at: <https://www.sitecproject.com/ about-site-c/project-overview $>$.

University of British Columbia. 2016. "Regulatory Process for the Site C Project." May.

United Nations Framework Convention on Climate Change. 2015. Paris Agreement. December 12.

World Bank Group - International Finance

Corporation. 2015. "Hydroelectric Power - A Guide for Developers and Investors." February. 
NOTES: 


\section{NOTES:}


NOTES: 


\section{ReCEnt C.D. Howe Institute Publications}

January 2019 Kim, Jacob, and Alexandre Laurin. "Mothers at Work: The Fiscal Implications of the Proposed Ontario Childcare Rebate.” C.D. Howe Institute E-Brief.

December 2018 Robson, William B.P., and Farah Omran. Wild Numbers: Getting Better Fiscal Accountability in Canada's Municipalities. C.D. Howe Institute Commentary 527.

December 2018 Found, Adam, and Peter Tomlinson. "Business Tax Burdens in Canada’s Major Cities: The 2018 Report Card.” C.D. Howe Institute E-Brief.

December 2018 Ambler, Steve, and Jeremy Kronick. Navigating Turbulence: Canadian Monetary Policy Since 2004. C.D. Howe Institute Policy Book 47.

November 2018 Richards, John. Pursuing Reconciliation: The Case for an Off-Reserve Urban Agenda. C.D. Howe Institute Commentary 526.

November 2018 Koeppl, Thorsten, and Jeremy Kronick. Tales from the Crypt - How to Regulate Initial Coin Offerings. C.D. Howe Institute Commentary 525.

November 2018 Fried, Jonathan T. Fried. "Anchoring Sustainable Growth in Disruptive Times" C.D. Howe Institute Verbatim.

November 2018 Robson, William B.P., and Farah Omran. Show Us the Numbers: Grading the Financial Reports of Canada's Municipalities. C.D. Howe Institute Commentary 524.

October 2018 Adams, Jason, Ken Chow, and David Rose. “Assessing Active Labour-Market Programs: How Effective Is Ontario Works?” C.D. Howe Institute E-Brief.

October 2018 Dachis, Benjamin. A Roadmap to Municipal Reform: Improving Life in Canadian Cities. C.D. Howe Institute Policy Book 46.

October 2018 Snoddon, Tracy. “The Rocky Road to Canada-wide Carbon Pricing." C.D. Howe Institute E-Brief.

October 2018 Sen, Anindya, and Rosalie Wyonch. Cannabis Countdown: Estimating the Size of Illegal Markets and Lost Tax Revenue Post-Legalization. C.D. Howe Institute Commentary 523.

October 2018 Laurin, Alexandre, and Farah Omran. Piling On-How Provincial Taxation of Insurance Premiums Costs Consumers. C.D. Howe Institute Commentary 522.

\section{SUPPORT THE INSTITUTE}

For more information on supporting the C.D. Howe Institute's vital policy work, through charitable giving or membership, please go to www.cdhowe.org or call 416-865-1904. Learn more about the Institute's activities and how to make a donation at the same time. You will receive a tax receipt for your gift.

\section{A REPUTATION FOR INDEPENDENT, NONPARTISAN RESEARCH}

The C.D. Howe Institute's reputation for independent, reasoned and relevant public policy research of the highest quality is its chief asset, and underpins the credibility and effectiveness of its work. Independence and nonpartisanship are core Institute values that inform its approach to research, guide the actions of its professional staff and limit the types of financial contributions that the Institute will accept.

For our full Independence and Nonpartisanship Policy go to www.cdhowe.org. 

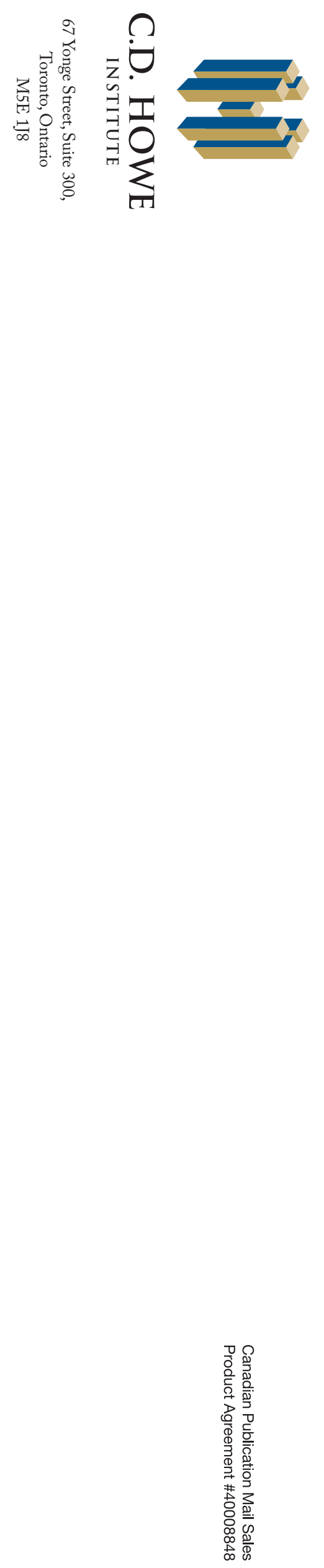